\title{
Hourly Employment
}

National Cancer Institute

\section{Source}

National Cancer Institute. Hourly Employment. NCI Thesaurus. Code C116002.

An employment arrangement where a worker is compensated a wage based on the number of hours worked. 